\title{
Sustainable Development Management of Local Territories in the Eastern Ukraine in Conditions of Military Conflict: Identification Criteria
}

\author{
By Yuliia Rohozian ${ }^{1}$, Svitlana Hrechana ${ }^{1}$, Olena Kuzmenko², Nataliia Derzhak², \\ Vitalii Kuchmenko ${ }^{4}$, Mykhailo Plietnov ${ }^{5}$
}

\begin{abstract}
Decentralization, which has begun and continues in Ukraine, has raised the living standards of local people to a new level by updating tools and methods of managing the sustainable development of such territories, updating a particularly balanced approach to planning and finding reliable sources. In this context, it is advisable to identify qualitatively the local area, which is not only a guarantee of their subjectivity and sustainability, but also the basis for the strategies forming for their socioeconomic development, the realism and effectiveness of which is based on sustainable development management as well as administrative and financial capacity of communities. However, as practice has shown, most local areas, although willing to identify their unique features, but do not know how to do it, because the current legal field in Ukraine does not regulate the procedure and criteria for such identification. This article was an attempt to research the managerial possibilities of creating a positive image of the territory through the sustainable development and choice of appropriate assessment parameters - the criteria for identifying the amalgamated territorial communities of Ukraine as local territories. As a result of the research, a model list of such criteria is proposed, which is sufficiently universal to determine the unique and typical characteristics of any territories, and also contains a specific subsystem that allows reflecting the individual features of territories close to the armed conflict zone in the Eastern Ukraine. Using this list will allow communities to form one or more images of the local area: from formal (real) to imaginary and special. It will help improve the results of communities and territories identification, the foundation for the sustainable development with marketing measures to promote communities as well as the formation of management decisions for their strategic and sustainable development, which will be best adapted to the realities of the current armed conflict.
\end{abstract}

Keyword: sustainable development management, identification criteria, local territories, amalgamated territorial communities, military conflict

\section{Introduction}

The extremely tense and contradictory present day is prioritizing the choice of the state regional policy vector for the effective sustainable development management of

\footnotetext{
| ${ }^{1}$ Department of Interregional Cooperation Problems, State Institution "V.K. Mamutov Institute of Economic and Legal Research of the National Academy of Sciences of Ukraine"

2Department of Business Economics and Entrepreneurship, SHEE "Kyiv National Economic University named after Vadym Hetman", Ministry of Education and Science of Ukraine

3Department of Public Administration, Management and Marketing, Volodymyr Dahl East Ukrainian National University, Ministry of Education and Science of Ukraine

${ }^{4}$ Department of Economic Security, Public Management and Administration, Zhytomyr Polytechnic State University, Ministry of Education and Science of Ukraine

${ }_{5}^{5}$ Department of Business Economics and Entrepreneurship, Volodymyr Dahl East Ukrainian National

University, Ministry of Education and Science of Ukraine
} 
the subregional level in order to create comfortable living conditions of the population and increase its level. To address this challenge, in 2014, in the context of the active phase of armed conflict, decentralization reform was launched, resulting in the successful progress of which nearly one thousand new territorial units - Amalgamated Territorial Communities (ATCs) - were operational in early 2020.

Newly formed communities have evolved into financially viable socioeconomic systems that have concentrated the human, industrial, transportation, land and other resources of the respective communities, increased the local government budget revenue base for reducing administrative and administrative expenditures, expanded powers and increased responsibility, opened new avenues development. The reforming pillars for local economic growth have allowed most of these local territories (territories within the amalgamated territorial communities) to improve living conditions for their residents as they have access to previously unreachable educational, medical, administrative, household, modern transport services for the sustainable development. Public service has come closer to people and its social standards have increased. The cohesion of communities has increased, and as enormous changes in the lives of their communities have become reality, the interest and involvement of residents in managing the development of the respective territories has increased. However, these positive developments have not taken place without a sufficient number of problems and mistakes to solve, the main ones being the reluctance of communities to unite for various reasons, the imperfection of regulatory support for reform, the lack of qualified personnel in local governments, the continuation of military conflict and decline in economic growth in the country. The reform is also stalled by the disproportionate amount of funds allocated by the state in the form of targeted subsidies and their real need to ensure the implementation of fixed social functions (financing of medicine, education, and other social expenditures). As money is increasingly distributed in manual mode rather than a fixed part of the budget or self-sustaining income of communities, the future of decentralization is increasingly uncertain.

All it leads to increased attention of the amalgamated territorial communities to conscious planning of future local territories within the region, effective formation of strategic vision, values and goals in their own socio-economic part of the sustainable development strategy and plans for its implementation, careful identification of reliable sources for programs and projects, including alternative budget. That is, the purpose of their management policy in such changing conditions should be to transform from a management entity to a management entity with the ability to independently maintain its capacity. However, "not all ATCs are able to independently determine their strategic priorities and goals, position themselves in the conditions of the internal and external environment" (Rohozian and Noskova 2017), so the need for qualitative identification of the amalgamated territorial community as a local one is actualized territory that needs appropriate positioning for further successful development and increase in the standard of living of the population. "The identification and positioning of an ATC should take place in the following main areas: identifying and exploiting the benefits of an ATC, shaping its attractiveness to investors, residents, business entities, qualified personnel by identifying positive ATC differences from other communities" (Ustymenko et al. 2019). But, as practice shows, most local territories, though expressing a desire to show their 
unique characteristics, are not able to do it qualitatively, since the current regulatory legal framework does not regulate the procedure and criteria for the implementation of such identification. As an alternative, the ATC can use a more or less established set of general indicators of socio-economic part of the sustainable development, which, with the appropriate qualifications and experience, will help to determine the image description. However, for individual communities and territories in close proximity to the war zone in eastern Ukraine, the list of identification criteria has significant differences, which justifies the need for a clear definition.

\section{The Purpose and Structure of the Research}

This article aims to expand the theoretical and methodological foundations of identification process of the amalgamated territorial communities of Ukraine, which is not only a pledge of the subjectivity and sustainability of the respective local territories, but also a basis for the formation of strategies for their socio-economic development, based on the realism and effectiveness of which managing sustainable development as well as achieving the administrative and financial capacity of communities.

The purpose of the research is to determine a systematic list of criteria for identifying local territories; providing it with the possibility of identifying specific territories in the immediate vicinity of the area of military conflict in the east of the country in order to create appropriate conditions for effective management of their sustainable development.

In order to achieve this goal, an appropriate research methodology was chosen, which included a combination of different methods and tools to collect, analyze and systematize the necessary primary and secondary information. The theoretical review is based on the regulatory and legal framework on the system of management actions for the strategic planning organization of the regional socio-economic and sustainable development and ATCs in Ukraine, as well as monitoring the implementation of relevant program documents. Much of the secondary data is provided through the use of official government and statistical reports, analytical and expert studies, and scientific content on relevant topics of regional and territorial sustainable development management.

The main part of the article contains an analysis of the conditions in which the creation and maintenance of the life of the amalgamated territorial communities in the process of decentralization through the prism of determining the need for their own uniqueness and limits to the permissible typicality of development, determine the approaches to the identification of local territories. Particular emphasis is placed on the study of managerial opportunities to create their positive image (vision) in the current conditions and in the future through the selection of appropriate assessment parameters - identification criteria. The formation of the real (formal), imaginary and special (selective or specific, reflecting the individual features of territories close to the zone of armed conflict in the East of Ukraine) was chosen among the many varieties of the territory image (vision). Based on this choice, the model will generate a model list (array) of criteria for identifying the local area, which includes three subsystems-lists, each of which reflects the ability to build the desired image (vision) or their totality. 


\section{Identification of Local Territories for the Sustainable Development: Nature and Criteria}

The main condition for sustainable development managing a local area (ATC) at present is the achievement of their administrative and financial capacity, which is based on active cooperation of local self-government bodies with the members of public and business with the effective implementation of strategic priorities and goals that are determined taking into account the local identity residents. Therefore, the identification of the amalgamated territorial community is turning into a profound factor of sustainable development, forming new approaches to it, laying a solid foundation for positioning and creating a community brand.

The identification of local territories will be understood as the procedure for establishing the similarities / differences of the ATCs by means of defined criteria and corresponding features, combining which reflects the uniqueness of a particular ATC against the background of others (Ustymenko et al. 2019).

Therefore, the essence of the identification process is to identify an appropriate set of values that are specific to this community of the local territory (communities united by the ATC territory), which to some extent characterize its typicality and difference, and also affect its sustainable development, which in the aggregate allows the inhabitants to internally embrace such values and identify themselves as belonging to this place and its social community. Its main task is to create an attractive image or vision of the local area, which is able to express competitive advantages and potential growth points, to become the basis for positive identification and a kind of signal for possible fruitful cooperation. The image of a territory is a set of emotional and rational representations that are formed when comparing all the features of a territory, the personal experience of people and rumors that influence the creation of a certain image (Schörghuber, 2000). The image of the territory is a set of characteristics that are reflected in the minds of people about a certain area with inherent cultural, aesthetic, historical and other competitive advantages, which create the basis for image formation (Havrylyuk, 2019). Image and vision are interrelated concepts that can manifest themselves in imaginary and real forms, be confirmed or disproven, classified according to the area of coverage, scope, social connections of group members, number of participants, etc. The image is primary because it is a reflection in the human psyche of external objects or phenomena, and thus formed naturally in the process of imagination. An image is formed on the basis of one or more images, that is, its creation is connected with the presence of special purposeful actions.

The complexity of the phenomenon of image, due to the variety of approaches to its vision and peculiarities of formation, in the context of decentralization takes on new shades. Amalgamated territorial communities were created not from scratch, but brought together into one whole already existing settlements, which at one time built the image or vision of the local territory, or even the brand. Therefore, at this stage of decentralization reform, the perception of the image (vision) of a newly formed community as wholly defined and sustainable and reflected in the mass or individual consciousness can vary greatly from person to person. Such pluralism can be offset by normalizing the image base of the vision of the territory in the context of its identification function (the ability 
of the target audience to perceive information about the positive or negative sides of the object in a short period of time without analyzing the entire amount of information (Vasilkonova, 2014)). Therefore, it is necessary to determine, first of all, the criteria for the selection of features, the combination of which reflects the uniqueness / difference of a particular community against the background of others because, that is, the criteria of identification as the boundary of its information base, because they are those indicators of the object of identification that characterize its essence, both identify and differentiate it from other similar objects.

Identification is a reflection of the amalgamated territorial community, but not so much in an "objective" context as in the sense that the local territory is perceived by existing or potential residents, guests or tourists, local or central government, entrepreneurs, investors, etc. That is, the kind of perception will be identified with the corresponding image (vision) of the territory, which allows us to propose the following types - formal, imaginary and special, and to distinguish for each of them the appropriate criteria. Figure 1 shows schematically an information base for the formation and systematization of such criteria.

Thus, the general data on the community (the ATC passport) and their capacity assessment for sustainable development make it possible to construct a sufficiently real, but somewhat reduced, formal image (vision) of the respective local area.

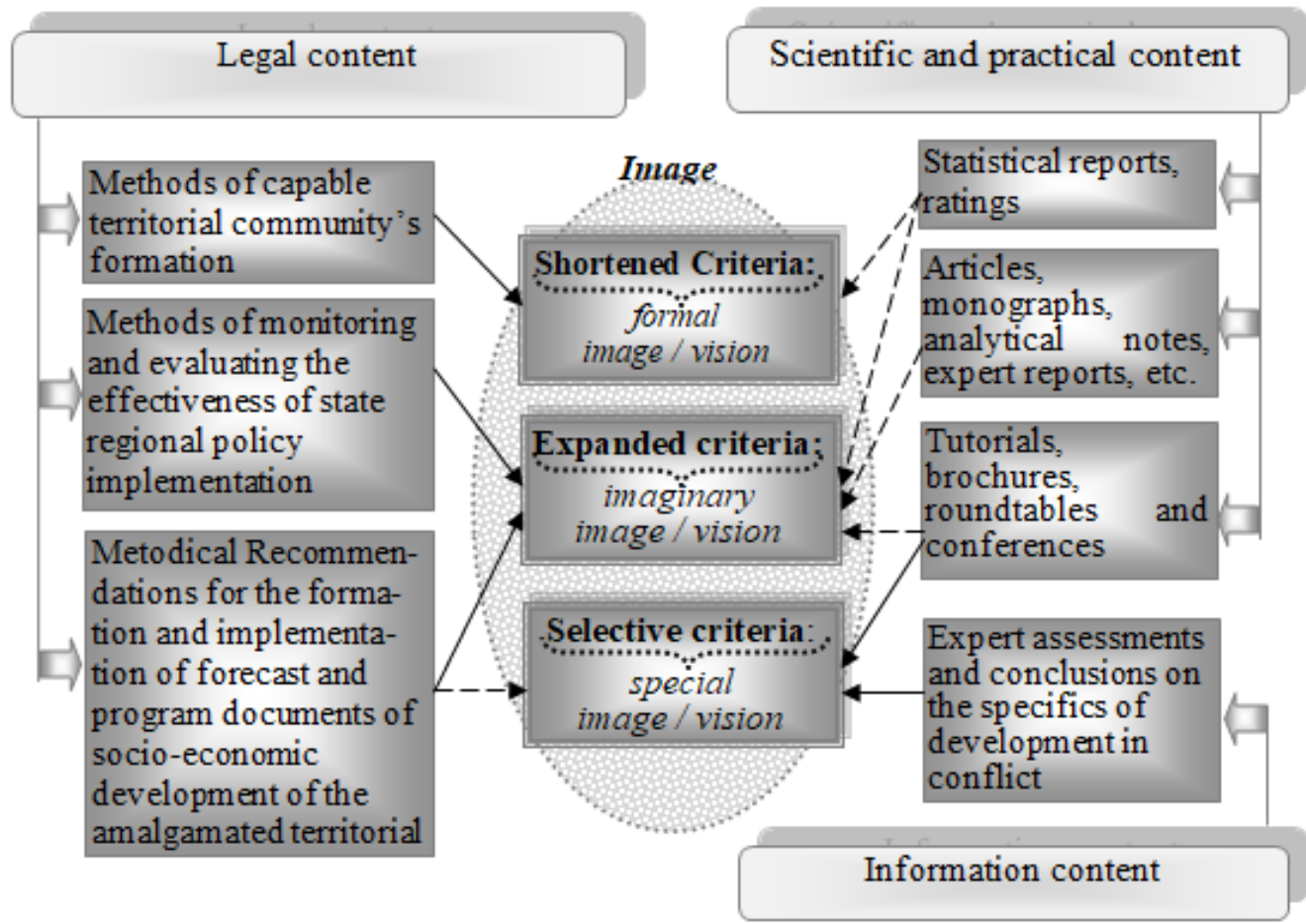

Fig. 1 Information base for selection of local territory (ATC) identification criteria

Source: own elaboration 
Reports on the socio-economic and sustainable ATC development, the rating (score) results of assessments and monitoring of the ATC development strategies implementation provide the information that allows to construct a more detailed but imaginary image (vision) of the local territory. To a greater extent, compared to the formal one, it reflects its uniqueness or difference against the background of other ATCs. Of particular value are the data matched in the dynamics, as they allow you to track the history of changes in ideas about ATC: as a result, they changed, what caused the appearance of certain images, and so on. Therefore, the indicators characterizing the state of sustainable ATC development by each component - economic, social, environmental, can be considered as the basis (quantitatively and qualitatively) for the formation of a criteria system for the ATC identification, since to obtain a complete picture of the uniqueness / difference of the territory additional administrative, geographical, or other information should also be considered.

Selective criteria are selected as a separate group in the information base scheme for the selection of local territory identification criteria. This approach reflects the opinion of the authors on the reflection in the development of a common positive image of the ATC influence of specific factors, under the constant or periodic action of which is the development of local territories in the immediate vicinity of the zone of armed conflict in the East of Ukraine, and which form such individual features determine their particular image.

The criteria for identifying the local territories for building a formal image can be determined in accordance with the CMU Resolution on April 8, 2015 No. 214 "On Approval of the Methods for the Formation of Capable Territorial Communities" (Cabinet of Ministers of Ukraine, 2015a). The list of indicators for determining the state of socio-economic development of the amalgamated territorial communities in Ukraine, which is regulated by the legal acts on monitoring the implementation of the Strategy for the Development of the ATC, would be more appropriate for forming an imaginary image. The main documents that form a sufficiently comprehensive list of such indicators are: ATC Resolution on October 21, 2015 No. 856 "On Approval of the Procedure and Methods for Monitoring and Evaluation of the Effectiveness of Implementation of State Regional Policy" (Cabinet of Ministers of Ukraine, 2015b) and Order of the Ministry of Regional Development, Construction, Housing and Communal Services of Ukraine «On approval of Methodical recommendations on the formation and implementation of forecast and program documents of socio-economic development of the united territorially community » No. 75 dated March 30, 2016. (Ministry of Regional Development, 2016). The process of determining the list of specific identification criteria that will allow us to form a specific perspective on the local territories of Eastern Ukraine should be based on information that emphasizes the specific features of the ATC and the region, that is, expert opinion on factors and problems of their sustainable development.

The above legal acts, on the one hand, provide meaningful lists of indicators on the basis of which the criteria for identification and construction of both formal and imaginary image of the respective local territory can be formed in the sustainable development context. On the other hand, these documents give a conceptual, purely theoretical view of the result of identification, not taking into account the peculiarities of the practical 
component of the process itself, as well as the various variations in the interpretation of the results. Therefore, the proposed information base, although normative, requires appropriate validation: exclusion, supplementation and systematization through the content of research produced by the scholars and practitioners in this field. In this context, let us consider the selection of possible criteria for each type in more detail.

\section{Criteria Definition for the Local Territories Identification}

\subsection{Formation of a short criteria list}

The local territories that have succeeded in achieving significant success in sustainable development and appropriately present their results (created an objectively positive image) are much more likely to become widely recognized and involved in cooperation. The simplest attempt to construct it by "a set of values, advantages and characteristics of a region, city or community that, usually not quantifiable but in need of qualitative research" (Gerencsér, 2019), is a reduced empirical assessment of the capacity of the locality or community concerned the territories of the amalgamated community according to the Methods of formation of capable territorial communities. Such communities are recognized as being able to provide, on their own or through appropriate local governments, an adequate level of public service provision, in particular in the fields of education, culture, health, social protection, housing and communal services, with regard to human resources, financial support and infrastructure development of the respective administrative and territorial unit. The method (Cabinet of Ministers of Ukraine, 2015a) contains a minimum list of quantitative and qualitative criteria that allow the identification of ATCs in the first approximation, since it allows to determine the physical and social characteristics of a place that characterize the perceived uniqueness of their residents and observers (tourists) (Bernardo et al., 2016).

The quantitative criteria for assessing the capacity of an ATC may include the socioeconomic indicators that affect the sustainable ATC development, namely: (1) the permanent population in the territory of a capable territorial community; (2) the number of pupils receiving education in general secondary education institutions located in the territory of a prosperous territorial community; (3) the area of the territory of a prosperous territorial community; (4) the fiscal capacity index of the prosperous territorial community; (5) the share of local taxes and fees in the budget revenues of a prosperous territorial community. They more characterize the financial capacity of the community (analytical dimension of identification), which are rated high, medium, or low on an appropriate scale.

To assess an administrative capacity, that is, the descriptive part of identification, the Methods of formation of capable territorial communities requires an ATC passport, which determines its constituents as qualitative identification criteria, despite the fact that most of them have numerical values, requiring in some cases the definitions of several components. 10 main and 24 additional indicators of the community passport, in our opinion, only 6 are the identification criteria and should be included in their short list, namely: (1) the number of settlements that are part of a capable territorial community; (2) estimated income volume of a prosperous territorial community; the number of education and health institutions maintained at the expense of the local governments 
budget; (3) the premises availability for the placement of state bodies, institutions exercising powers in the field of law enforcement, registration of civil and property rights, pension, social protection, fire safety, treasury services; (4) the premises availability for the local governments placement; (6) the existence of an administrative services center.

Thus, the list (the first subsystem of the model list) of criteria, consisting of 5 quantitative and 6 qualitative elements, allows forming a clear idea of the potential ability of the local area to provide an adequate level of public services to its residents. That is, it can build a real image and formal image of the community, which traces its main characteristics in a formal context (the ability to provide the population with the necessary social and administrative services of sufficient quality), the combination of which reflects the advantages and disadvantages of a particular community against the background of others. However, it is difficult to determine the identity of the local area concerned by shortened criteria alone, because they do not reflect both current and potential features of its sustainable development.

\subsection{Criteria selection for the detailed list}

Typically, the results of a comprehensive analysis of the reports to monitor the implementation of their sustainable or socio-economic development strategies are used to determine the changes occurring in the local territories and regions development. However, in order to qualitatively evaluate such changes over others, the results of the ratings are most useful. This approach was introduced by the Ministry of Regional Development, Construction, Housing and Communal Services of Ukraine (now the Ministry for Communities and Territories Development of Ukraine) to monitor and evaluate the effectiveness of the implementation of state regional policy. Starting from 2016, each quarter (Cabinet of Ministers of Ukraine, 2015b), a rating assessment of the socio-economic part of the sustainable development of regions is conducted: 64 indicators annually, 27 of them quarterly. The interpretation of these indicators as expanded identification criteria meets all the necessary requirements for this procedure. Most of the information provided by the groups presented is based on official statistics on the socio-economic development of the regions. Based on the comparison of their absolute values or in the dynamics (indices, growth rates), the place of the region among others is determined.

However, not all of the rating indicators used to evaluate the regions can be incorporated for use in identifying local territories, either because of the difference in assessing the development of a region and settlement or their associations, or in the absence of such community-based statistical observations. That is why the "regional" set of indicators needs to be adjusted to the provisions of the Methodical Recommendations on the Formation and Implementation of the Forecasting and Programming Documents of the Social and Economic Development of the Amalgamated Territorial Community No. 75 (Ministry of Regional Development, 2016). In addition, some indicators at the regional and subregional levels coincide, some differ in units of measurement and approaches to determination, and some are not informative in the identification of ATCs, and so on. This means that their validation to the detailed list of criteria for identifying local territories requires a special approach, the simplified scheme of which is shown in Figure 
2.

Before giving a description of the proposed validation process, some nuances of drawing should be noted immediately. First, because of their considerable volume, the scheme does not give the names of indicators of sustainable development, but only determined their number in their respective groups by the names corresponding to the current regulatory and legal content. Second, the total number of criteria included in the expanded list (40 criteria) is not equal to the arithmetic sum of the indicators selected for each group, as 13 of them belong to both lists of socio-economic development indicators. Thirdly, the figure does not separately indicate the impact on the formation of the expanded list of scientific and practical content, as was foreseen in Figure 1 because its validity is embedded in the validation process.

The comprehensive list of criteria included, first and foremost, the subregional level indicators, which were almost complete, with the exception of the three ATC indicators from the "Quality and Accessibility of Public Services" group, namely: the proportion of graduates from non-tertiary educational establishments who received independent education as a result of external assessment in mathematics, Ukrainian language and literature, foreign language 160 points and above. They were rejected because of the ambiguity and lack of evidence of influencing the identification and identity of the community, the advantages and disadvantages of a particular local area in the field of educational services.

Further, the list was supplemented by the indicators used in the rating of the region and passed the relevant validation of scientific and practical content. Systematization of the database of the State Statistics Service of Ukraine regarding regional statistics (State statistics service of Ukraine, 2019), publications of international organizations experts operating in Ukraine, providing support to the local governments in the field of decentralization and regional policy, namely: UNDP, SDC, GIZ, SIDA, Global Affairs Canada, Council of Europe, USAID, Renaissance Foundation, Eastern Europe Foundation (Vasy 'lchenko et al., 2015; Methodology of Strategic Planning, 2016; Ol chak, 2017), research by national scientists (Kozyrieva, 2016; Fedulova, 2017; Andrusiv et al., 2020; Shults et al., 2019; Zablodska et al., 2020a) allowed to conclude the need to supplement the final indicators, namely: the volume of sales per capita, the level of registered unemployment, real wages, the number of criminal offenses per 1,000 people, the rate of increase (decrease) in local budget revenues (without transfers). These indicators are very informative, and in those areas that are not sufficiently covered by the baseline indicators of monitoring the status of ATC. As to the sources of obtaining information, local governments own it or have the opportunity to obtain it. In any case, the presented list of criteria for the imaginary image of the local area is not something strictly mandatory to use, so in the absence of any information, some indicators may be excluded or replaced by similar ones.

As a result, a list (the second subsystem of the model list) of criteria was obtained, which provides a clear procedure for defining and conceptual frameworks for ATCs identification and construction of the local territory image or vision. 


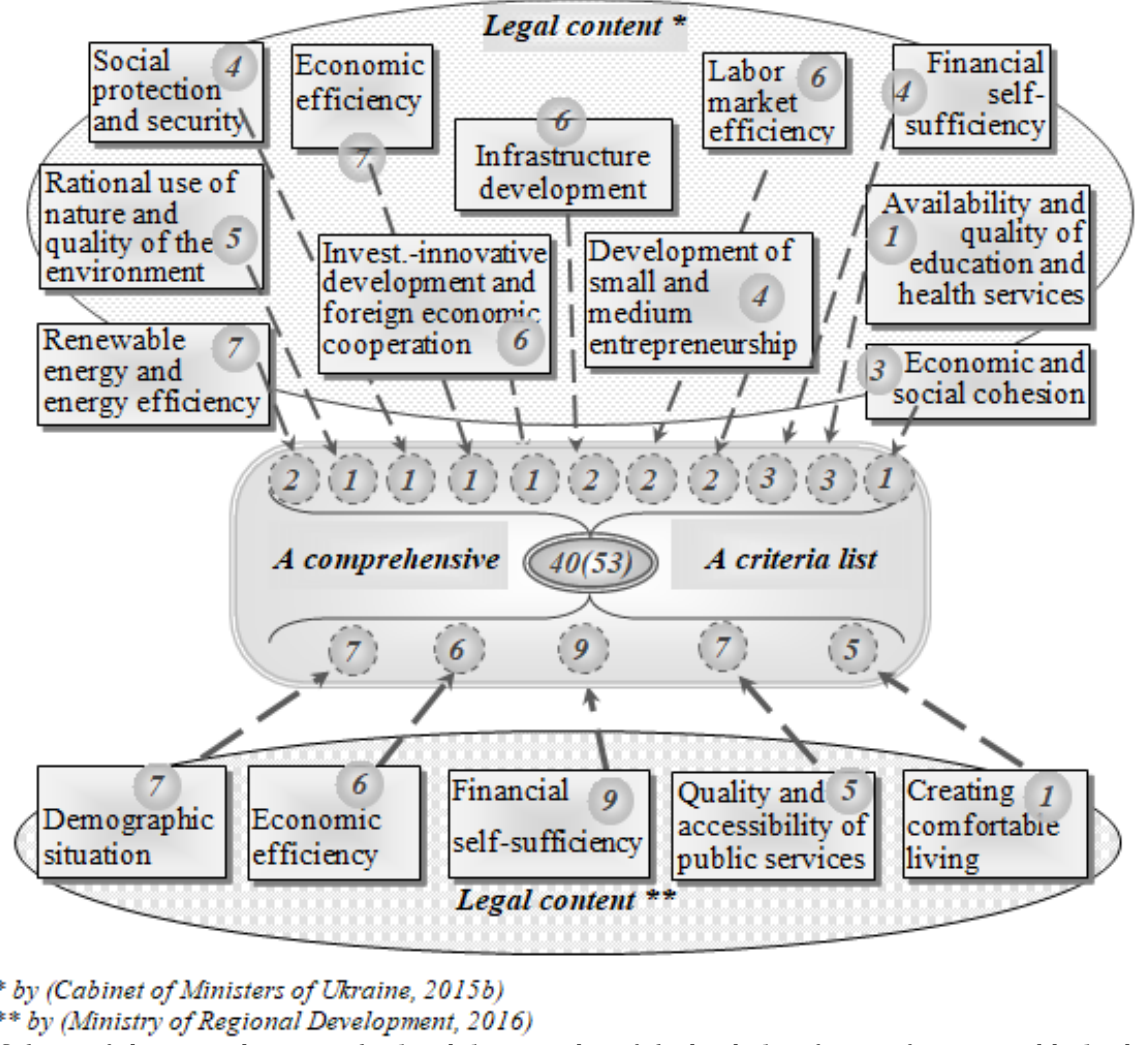

Fig. 2 Scheme of elements selection to the detailed criteria list of the local identification for sustainable development Source: own elaboration

It consists of: (1) the total rate of dropout of the rural population, per 10 thousand people of the existing rural population; (2) the volume of industrial production per capita; (3) the volume of capital investment per capita; (4) the growth rate of local budget revenues (excluding transfers); (5) the revenue of the general fund of the ATC budget; (6) capital expenditures of local budgets (excluding transfers from the state budget) per capita; (7) the number of small and medium-sized enterprises per 1,000 population; (8) the unemployment rate (according to the ILO methodology); (9) real wages index; (10) the proportion of households having access to the Internet at home; (11) the level of implementation of energy-saving light sources in the outdoor lighting of settlements; (12) the proportion of households that have entered into credit agreements within the framework of mechanisms to support energy efficiency measures in the housing sector at the expense of the state budget (including co-financing from local budgets); (13) the proportion of preschool children covered by pre-school institutions, in the total number of preschool children; (14) the proportion of children enrolled in extracurricular education; (15) the proportion of children for whom commuting to and from home is organized in the total number of students in need; (16) the number of criminal offenses per 1,000 population; (17) the share of settlements where separate collection of solid waste is introduced; (18) the size of the permanent population; (19) the population of the 
population aged 16-59; (20) the number of children under 16; (21) demographic burden per 1,000 working-age people; (22) natural population growth (decline); (23) internal migration of the population within the settlements of the ATC; 24 ) the number of cooperatives per 1,000 population; (25) the length of roads constructed with local pavement coverage in the reporting year; (26) the volume of funding for regional development projects implemented on the territory of an ATC; (27) the number of regional development projects implemented on the territory of an ATC; (28) the share of the basic grant in the revenue of the general fund of the ATC budget (without subsidies); (29) the share of development budget expenditures in the total expenditures of the ATCs (without taking into account the own revenues of budgetary institutions); (30-34) the amount of revenues to the budget of the amalgamated territorial community from payment of the personal income tax (land payments; single tax; excise tax; real estate tax) per person; (35) provision of general practitioners by the family physicians per 1,000 persons of the existing population at the end of the year; (36) the average occupancy of a group of pre-school educational establishments; (37) the average occupancy of the ATC general education classes; (38) the share of households with centralized water supply in the total number of households of ATC; (39) the proportion of households with centralized sewerage in the total number of households of ATC; (40) the share of settlements that have concluded contracts with service organizations for the removal of solid household waste, in the total number of settlements of gas storage facilities.

However, this subsystem list, although quite extensive, allows identification of local territories in an imaginary way that covers almost all spheres of life but does not allow to reflect the individual features of areas that are in close proximity to the armed conflict area of Ukraine. Currently, such communities are identified only by names that match the names of cities or towns in the areas where they are formed, and are positioned only as ATCs close to the conflict, most often perceived by potential guests or tourists with caution, and partners or investors as partner's factor. Therefore, a positive image of such territories should be built within the framework of the managerial decisions to intensify the sustainable development and expansion of inter-municipal and inter-regional cooperation, based on the specific features, the results of which should form a corresponding additional list of selective criteria.

\subsection{Criteria defining for the military conflict impact on the local territories sustainable development in the Eastern Ukraine}

At the beginning of the conflict, the experts from the European Union, the United Nations and the World Bank Group (UNDP, 2015) acknowledged its significant and detrimental impact on the well-being of the population, social, ecological and economic conditions of life, demonstrating the collapse of the Ukrainian economy, destabilization of the financial system, significant material resources through the physical destruction of housing, infrastructure, social and industrial sites, emphasizing. Estimates of the magnitude of such losses, including indirect ones, are ambiguous and vary significantly depending on the time, period and methods of estimation. At the beginning of Russia's armed aggression, they were estimated at about \$ 0.9 billion (Ukraine. Government Portal, 2014). Next year, the foreign experts estimate infrastructure losses at \$1.26-10 billion (UNDP, 2015; Adarov et al, 2015). Two years after the conflict began 
the estimates rose to $\$ 60-72$ billion (Kasperovich, 2018; Aslund, 2018), though some $\$$ 300 billion in estimates have been published (Kravchenko, 2018). In 2019, more thorough research has summarized material losses in the range of $\$ 32-\$ 90$ billion (Vyshnevskyi, 2019; Prokaza, 2019; Bluszcz and Valente, 2019; Pashkov (eds.), 2019). The fact that the major losses were suffered by the Luhansk and Donetsk regions, which were directly involved in hostilities and suffered the brunt of destruction and casualties, remains unchanged in such research.

In the five years of confronting Russia's external aggression, the situation in the region has changed for the better but before the conflict is resolved, or at least before its deescalation, it is still far enough. The fighting, although not systemic, but continues to kill people, ceasefire does not occur, although the shelling is recorded mostly along the demarcation line. In such circumstances, the civilian population does not cease to feel the closeness of hostilities, and the destructive power of the conflict continues to adversely affect the livelihoods of the Luhansk and Donetsk regions, hyperbolizing outdated problems and creating new ones, creating a negative region image.

1. The loss of human resources, assets and property as a result of the conflict has significantly reduced the material resources of local self-government, which in the long run continues to offset the development potential of local territories and the region as a whole. Thus, 41-44 thousand people were victims of the conflict in Ukraine, of which 13-13,000 were killed (The UN counted, 2019). More than 1.3 people have become internally displaced. The region has lost $17,000 \mathrm{~km} 2$ of territory, nearly half of its industrial potential (much of its assets have been exported to the Russian Federation), control of major coal mining areas (81 mines out of 119), etc. (Pashkov (eds.), 2019). The loss or damage of critical infrastructure has led to disruptions in operations, and in some places, declines, in the fuel and energy sector, in transport, in water supply and sewerage systems. Unfortunately, all these destructive factors of the conflict continue to destabilize the socio-economic situation in the local territories of the region, reducing the already damaged production potential of the region, namely: reduction of production capacity and low level of their loading; high cost of energy and materials; falling demand for production of basic industries in foreign markets; insufficiently developed internal market of industrial production, isolation of the Luhansk region from the unified power grid of Ukraine; reduction of the internal resource base of the fuel and energy complex; high degree of deterioration and obsolescence of production and technological equipment; temporary suspension of movement of goods through the line of contact; narrowing of export potential and reduction of its volume; etc. (Ryazanova, 2017; Economic and legal means of stimulating the Donbass development, 2019; Zablodska, 2020b). All this leads to an increase in the unemployment rate, as well as a gradual decrease in the standard of the population living and its solvency.

2. The fall in investment attractiveness of the region to a catastrophically low level, which resulted in almost stopped the inflow of foreign investment and curtailed domestic investment. The armed conflict has increased the risks of investment activity across Ukraine, but in frontline areas alone, the amount of capital investment in 2014 has more than halved. In 2015, its further decline occurred: in Donetsk region 1.5 times, in Luhansk - more than 2.5 times compared to the previous year. Since 2016, positive investment dynamics have recovered, but the volume of investment resources attracted 
to the economy remains low compared to other regions (Danylyshyn and Snigova, 2019). This is explained by the loss of the Donetsk and Luhansk regions of their important advantages (availability of balanced on the basis of "qualification - price" of labor resources, branched transport infrastructure and advanced energy system, etc.) during armed conflict and increased investment risks due to the proximity of hostilities. The decrease in investment attractiveness and lack of investment mainly discourages sustainable development of the local territories in the region.

3. Poor level of infrastructure for business and population. During the conflict, significant transit potential of the region was destroyed. As the railway connection was significantly disrupted and partially not restored through the occupation (especially in the Luhansk region), the established logistics of the transportations was destroyed. The main burden was the road transport. As a result, the road infrastructure, which had not been of high quality before the conflict began, did not withstand a critical load: the road surface in some areas was completely destroyed, which also had the effect of reducing traffic. In the five years of conflict (including the introduction of a temporary cessation of goods movement through the collision line) in February, road freight transport has decreased by almost 2 times in Donetsk region and more than 7 times in the Luhansk region. The situation is similar with regard to the transportation of passengers: in 2018 in Donetsk region buses transported passengers more than 4 times less than in 2014, and in the Luhansk region about 8.5 times (State Statistics Service of Ukraine, 2017, 2019). Social infrastructure has also undergone significant reductions in its load on its balance.

Due to the temporary occupation of a part of the region, the network of secondary education institutions has more than halved (as of 2019 compared to 2013), vocational (vocational-technical) educational institutions 2.7 times, higher education institutions 2.2 times. The health sector has suffered even more: the number of doctors has decreased 3.4 times in 2019 compared to the prewar level in 2013, the number of hospital beds is more than three times each indicator, the planned outpatient capacity is 2.5 times (Verner (eds.), 2018; State Statistics Service of Ukraine, 2019). A similar situation was also encountered by the network of library facilities, theaters and museums. At present, as the size of the region and the population decreases, the burden on social infrastructure has increased as a large proportion of IDPs have settled in Donetsk and Luhansk regions (Horbulin et al., 2015). In addition, it is in this region that the so-called "pension tourism" is most widespread, when residents of the occupied territories from time to time travel to the territory under the control of the Ukrainian government to receive appropriate social payments and paperwork, which increases the burden on the respective institutions.

This state of infrastructure significantly impairs the accessibility of administrative, transport and social services to the residents of local territories of Eastern Ukraine. Local governments should increase their costs to remedy this situation. However, in the absence of government programs, it is difficult enough to do so, because of the increased political and economic risks in communities close to the area of hostilities, it is virtually impossible to cover the costs of rehabilitation and development of communal infrastructure, as well as to secure sustainable development through private investment (Zhalilo et al, 2019).

4. The establishment and functioning of civil-military administrations (CMAs), through 
the failure of local governments to exercise their powers over a long time, hinders decentralization. At present, local self-government bodies whose functions are performed by the CMAs are structures in some territorial communities - structures that are included in the vertical of the state executive power at 3 levels (regional, district, settlements). If such a community has the desire to create an ATC or join an existing one, it is difficult to resolve this issue because it is the local authority, not the CMA that can consider and approve the decision. In addition, the Central Election Commission of Ukraine does not call the first elections in 11 front-line ATCs $(7$ in Donetsk region and 4 in Luhansk), explaining that it is impossible to organize and hold armed aggression against Ukraine by the Russian Federation.

This incomplete list of the negative effects of military conflict on the livelihoods of local territories of Eastern Ukraine, which can be expanded by less determinative factors, points to particular aspects of the decentralization reform progress and community sustainable development in the region. Based on it, and taking into account the experts' proposals for solving the problems of development of the territories located in close proximity to the war zone and demarcation line (Novikova, 2016; Halhash, 2019; Ustymenko eds., 2019), it is possible to define selective (special) identification criteria that distinguish territory data among other reform participants. We offer the following list of them: (1) the cost of the objects of irretrievably lost infrastructure; (2) the cost of the renewed infrastructure; (3) the rate of increase in infrastructure renewal costs; (4) distance to the demarcation line; (5) the number of internally displaced persons officially registered in the ATC; (6) the availability of IDP jobs; (7) the number of territorial development projects initiated in the ATC; (8) the presence in the strategy of socioeconomic development (as part of the sustainable development) of local territory goals for infrastructure transformation and service delivery; (9) the number of territorial community cooperation agreements; (10) the number of public-private partnership agreements. This list may be extended at will or need, but we propose to limit ourselves to this array of identifiers, which in our view is sufficient and informative to identify the unique features of specific "conflict" territories.

It is the final element that completes the model list of criteria for identifying local territories as a union of three subsystems - formal, expanded and selective. Its main advantage is that it provides only an indicative list of identifiers for identifying typical and distinctive features of the local area, a combination of which reflects its uniqueness against the background of others, which may be narrowed or expanded as needed and as appropriate. However, its introduction gives a unique opportunity to form together, individually or selectively different images (visions) of the local territory: from formal (real) to imaginary and special, since it contains a subsystem-list of selective criteria that allow distinguishing the sustainable development of individual territories. In this regard, the role of identifying communities and territories is enhanced, the results of which are a good foundation for both the sustainable development of marketing measures for the communities promotion and the formation of management decisions on their strategic development, which will be as adapted as possible to the realities of specific communities. 


\section{Conclusions}

The amalgamated territorial communities were created as a result of the decentralization reform introduced in Ukraine have transformed their own local territories into financially viable socioeconomic systems, which have managed to create more comfortable living conditions for their residents. To support this start-up trend in today's tense environment, the local governments need to make increasing efforts to manage the sustainable development of local areas, focusing on sound responsible planning and finding reliable sources of funding. That is, their policy should be to transform the amalgamated communities from facilities to management entities with capacity to provide their own capacity as the main condition for their sustainable development according to the goals defined taking into account the local identity of the community and its inhabitants. Therefore, the identification of the amalgamated territorial community as a local territory becomes a deep factor of sustainable development, forming new approaches to its management, laying a solid foundation for positioning and creating your own brand. It is determined that the identification of local territory is the process of forming an appropriate set of values inherent in this community of local territory, which to some extent characterize its typicality and difference, influence its sustainable development, allows the residents to internally accept such values and identify themselves as belonging to this place and its social community. The most useful tool for its implementation is the use of a set of appropriate criteria, as it gives the most accurate results due to the determinacy of the original data for calculations and is adapted to large amounts of processed information.

It is emphasized that in the process of identification it is created an attractive, positive image of the local territory, which is able to express both competitive advantages of this amalgamated community and its potential growth points, become a basis for positive identification (image formation) and a kind of signal for possible fruitful cooperation. It is noted that image and vision are interrelated concepts that can be manifested in imaginary and real forms, be confirmed or refuted, classified depending on the area of coverage, scope, social ties of group members, number of participants, and their perception may vary greatly from person to person. To eliminate such shortcomings, it is proposed to standardize the information base for the formation of the image of the territory in the context of its identification function, i.e. to determine the criteria for selecting features, combining which reflects the uniqueness / difference of a particular community.

As a result of normative legal generalization acts, scientific practical content within the direction of research chosen in the article, as well as expert assessments and conclusions on the specifics of territorial development in the conflict, input and output parameters of information base for constructing local community image are determined (formal) set of criteria, imaginary in detail, special (for territories in the immediate vicinity of the zone of armed conflict in eastern Ukraine) for the sample mea list of criteria for identification.

It is proposed to determine the abbreviated (formal) set of criteria for the local territories identification on the basis of indicators incorporation provided by the Methods of formation of capable territorial communities. Detailed list of criteria is based on the validation of indicators defined by the procedure and methods for monitoring and 
evaluation of the effectiveness of state regional policy, guidelines for the formation and implementation of forecast and program documents of socioeconomic and sustainable ATC development in whole, adjusted in accordance with the scientific and practical provision content. The generalization of expert assessments and the official reports on the state of socioeconomic development of the ATC Luhansk and Donetsk regions, on the territory of which or in the immediate vicinity of which the hostilities took place, and which bore the main burden of losses, allowed to identify the main pain points, which feels the destructive power of conflict. Based on this list of negative impacts on the life of local areas in eastern Ukraine, as well as taking into account the proposals of experts to address the sustainable development of these areas, a set of selective (special) identification criteria was formed, sufficient and informative to identify unique features of special "conflict" areas.

As a result of combining abbreviated, expanded and selective sets of identification criteria, their model list is formed, which is, on the one hand, universal for determining unique and typical characteristics of any territories, and on the other is exceptional due to the specific subsystem that allows to reflect the individual features of the territories close to the zone of armed conflict in the East of Ukraine during such identification. Its application allows local governments or independent professionals to form together, separately or selectively different images (vision) of the local area: from formal (real) to imaginary and special, developing management measures for the promotion of territories and their sustainable development.

\section{References}

Adarov, A., Astrov, V., Havlik, P. et al. (2015). How to Stabilise the Economy of Ukraine. Final Report [online]. The Vienna Institute for International Economic Studies. Available at: https://wiiw.ac.at/how-tostabilise-the-economy-of-ukraine-dlp-3562.pdf. last visited 25 June 2020.

Andrusiv, U., Simkiv, L., Dovgal, O. et al. (2020). 'Analysis of economic development of Ukraine regions based on taxonomy method'. Management Science Letters. 10(3), pp. 515-522. DOI: 10.5267/j.msl.2019.9.029.

Aslund, A. (2018) 'Kremlin Aggression in Ukraine: the Price Tag'. [online]. Atlantic Council. 19 March. Available at: https://www.atlanticcouncil.org/publications/reports/kremlin-aggression-inukraine-the-price-tag. last visited 30 June 2020.

Bernardo, F., Almeida, J. and Martins, C. (2016). 'Urban identity and tourism: different looks, one single place'. Proceedings of the Institution of Civil Engineers-urban Design and Planning. 170 (5), pp. 205-216.

Bluszcz, J. and Valente, M. (2019). The War in Europe: Economic Costs of the Ukrainian Conflict. [online]. Available at: https://www.diw.de/documents/publikationen/73/diw 01.c.622006.de/dp1804.pdf. last visited 9 July 2020.

Cabinet of Ministers of Ukraine. (2015). On Approval of the Methods for the Formation of capable Territorial Communities. Resolution adopted 8 April 2015 № 214. Available at: https://www.kmu.gov.ua/npas/248113527. last visited 9 July 2020.

Cabinet of Ministers of Ukraine. (2015). On Approval of the Procedure and Methods for Monitoring and Evaluation of the Effectiveness of Implementation of the State Regional Policy. Resolution adopted 21 October 2015 No 856. Available at: https://www.kmu.gov.ua/npas/248594766. last visited 10 July 2020.

Danylyshyn, B. and Snihova, O. (2019). Formation of economic development model of Donbass in the terms of formation of new regional policy. Kyiv: KPI im. Ihoria Sikorskoho, Politekhnika.

Fedulova, S. (2017). 'The problem of assessment of socio-economic development of regions and modeling their nonlinear dynamics' in Ekonomichna kibernetyka: modeliuvannia sotsialno-ekonomichnykh system. Dnipro: Porohy, pp.305-317. 
Gerencsér, I. (2019). 'The role of individual responsibility in territorial development'. Economic and Social Changes: Facts, Trends, Forecast. 12 (4), pp. 220-233. DOI: 10.15838/esc.2019.4.64.14

Halhash, R.A. (2019). 'The Natural Resource Potential and Opportunities to Mobilize Resources for the Development of Industrial Clusters and Smart-Specialization of the Luhansk Region'. Business Inform. 7, pp. 79-85.

Havryliuk, A. (2019). 'On the value principles of marketing construction "mode - image - brand reputation of the territory" as the priority of public policy in the field of tourism in Ukraine'. Investytsiyi: praktyka ta dosvid. 1, pp. 76-83. https://doi.org/10.32702/2306-6814.2019.1.76

Horbulin, V., Vlasiuk, O., Libanova, E. et al. (2015). Donbas and Crimea: the price of return. Kyiv: NISD.

Kasperovich, Yu. (2018). 'Methodical Approaches to estimation fiscal losses of Ukraine due to hybrid war by Russian Federation'. Ekonomika ta derzhava. Vol. 12. https://doi.org/10.32702/23066806.2018.12.8.

Kozyrieva, O. (2016). Theory and practice of differentiation research of social and economic development of Ukraine's regions. Kharkiv: FOP Liburkina L.M.

Kravchenko, V. (2018). Russia's aggression against Ukraine: the amount of losses and the possibility of reparations. [online]. Espreso.TV. Available at: https://espreso.tv/article/2018/03/30/ agresiya rosiyi proty ukrayiny obsyagy vtrat i mozhlyvosti reparaciy. last visited 7 July 2020.

Methodology of Strategic Planning for the Development of United Territorial Communities in Ukraine. (2016). Available at: https://surdp.eu/uploads/files/SP_OTG_Methodology_UA.pdf. last visited 7 July 2020.

Ministry of Regional Development, Construction and Housing and Communal Services of Ukraine (2016). On Approving the Methodological Recommendations on the Formation and Implementation of the Forecast and Program Documents of the Socio-Economic Development of the Amalgamated Territorial Community. Order adopted 30 March 2016. No 75. Available at: http://www.minregion.gov.ua/wpcontent/uploads/2016/05/Nakaz ---75 30.03.2016.pdf. last visited 8 July 2020.

Novikova, O., Amosha, O., Antoniuk, V. et al. (2016). Internally displaced persons: from overcoming obstacles to the success strategies. Kyiv: National Academy of Sciences of Ukraine. Institute of Industrial Economics.

Ol'chak, M. (2017). Participative strategic planning in local government bodies. Guidance for Amalgamated Territorial Communities. Warszawa: Fundacja Rozwoju Demokracji Lokalnej. Available at: https://decentralization.gov.ua/uploads/library/file/23/STRATEGIC PLANNING MANUAL standard version 9MB.pdf. last visited 8 July 2020.

Pashkov, M (eds.) (2019). 'The war in Donbas: realities and prospects of settlement'. National Security and Defense. 1-2 (177-178), pp. 2-172. Available at: http://razumkov.org.ua/uploads/journal/ukr/NSD1771782019 ukr.pdf. last visited 9 July 2020.

Prokaza, D. (2019) Losses of Donbass: how much did the occupation of the region cost for an economy? [online]. Hromadske. Available at: https://hromadske.ua/posts/vtrati-donbasu-skilki-koshtuvalaekonomici-okupaciya-regionu. last visited 9 July 2020.

Riazanova, N. (2017). 'Comprehensive damage assessment and prospects for the recovery of the eastern regions of Ukraine' in Hybrid war in eastern Ukraine in an interdisciplinary dimension: origins, realities, prospects for reintegration: collection of scientific works. Starobilsk: Luhansk Taras Shevchenko National University, pp. 88-95.

Rohozian, Yu. and Noskova, S (2017). 'Interregional cooperation as a prerequisite for the economic development of amalgamated territorial communities in Ukraine'. Baltic Journal of Economic Studies. 3(5), pp. 383-390. https://doi.org/10.30525/2256-0742/2017-3-5-383-390

Schörghuber, K. (2000). Standortmarketing. Erkennen und Nutzen von Standortchancen: vom Einzelstandort bis zur ganzen Stadt. (Edition Marketingforschung für die Praxis 2). Linz.

Shults, S., Maksymchuk, M., Simkiv, L. et al. (2019). 'Problems of Strategic Development of Regions of Ukraine Using Smart Specialization Concept'. Proceedings of the 2019 th International Conference on Modeling, Development and Strategic Management of Economic System (MDSMES 2019). https://dx.doi.org/10.2991/mdsmes-19.2019.52.

State Statistics Service of Ukraine. (2017). Transport and communication in Ukraine [online]. Available at: http://www.ukrstat.gov.ua/druk/publicat/kat u/2018/zb/08/zb tr2017pdf.pdf. last visited 10 July 2020.

State statistics service of Ukraine. (2019). Regional Statistics. [online]. Available at: http://www.ukrstat.gov.ua/. last visited 10 July 2020. 
The UN counted the victims of hostilities in Donbass among the civilians and combatants. (2019) [online]. Available at: https://www.radiosvoboda.org/a/oon-zvit-ghertvy-donbas/30272212.html. last visited 8 July 2020.

Ukraine. Government Portal. (2014). Volodymyr Groysman called a preliminary assessment of the cost of restoring Donbass and meeting the needs of displaced persons. Available at: https://www.kmu.gov.ua/ua/news/247600303. last visited 10 July 2020.

UNDP Ukraine. (2015). Peacebuilding Assessment: An Analysis of the Impact of the Crisis and Needs in Eastern Ukraine. Part I: Summary report. Available at: https://www.ua.undp.org/content/ukraine/uk /home/library/poverty/Recovery_and_Peacebuilding_Assessment_ukr_vol1.html. last visited 9 July 2020.

Ustymenko, V. (eds.) (2019). Economic and legal means of stimulating the Donbass development. Kyiv: National Academy of Sciences of Ukraine. Institute of Economic and Legal Research.

Ustymenko, V., Zablodska, I., Burbelo, S. et al. (2019). 'Identification and Positioning of the United Territorial Municipalities: Methodical Tools'. Economics and Law. 1(52), pp. 44-50. https://doi.org/10.15407/econlaw.2019.01.044

Vasy 'l'chenko, G., Parasyuk, I., and Yeremenko, N. (2015). Territorial community development planning: a manual for local government officials. Association of Ukrainian Cities. Kyiv: VI EN EJ.

Vasilkonova, E. (2014). 'Development of the Theory of Image of Territories as an Active Tool for Regional Management'. Business Inform. 12, pp. 463-468.

Verner, I. (eds.) (2019). Statistical publication regions of Ukraine 2018. Part II. Kyiv: State Statistics Service of Ukraine.

Vyshnevskyi, Yu. (2019). What has Ukraine, Russia and the West lost from the five-year conflict in Donbass? Available at: https://www.dsnews.ua/minskiy pat/shcho-vtratili-ukrayina-rosiya-ta-zahid-vid-pyatirichnogo-konfliktu-02092019230000. last visited 9 July 2020.

Zablodska, I., Hrechana, S., and Zablodska, D. (2020).'The Identification of the Luhansk Region and the Region Act's According to the Qualification of Their Sustainable Development in the Conditions of the Joint Forces Operation'. Problemy ekorozwoju - Problems of sustainable development. 1(15), pp. 197-210.

Zablodska, I., Melnykova, A., and Zablodska, D. (2020). 'Development of the Luhansk region in the terms of military conflict: aspect of positioning' in Forecasting and planning of economic development: microeconomic and macroeconomic levels. Riga: Izdevnieciba "Baltija Publishing".

Zhalilo, Y. (eds.) (2019). Decentralization of power: an agenda for the medium term, Kyiv: NISD. 